\title{
WIDESPREAD HEMATOGENOUS METASTASES AND TROUSSEAU'S SYNDROME IN GASTRIC ADENOCARCINOMA
}

\author{
Vitorino Modesto dos Santos, Denise Bertulucci Rocha Rodrigues, Eumênia Costa \\ da Cunha Castro, João Carlos Saldanha, Sheila Soares, Vicente de Paula Antunes \\ Teixeira and Marlene Antônia dos Reis
}

RHCFAP/3042

SANTOS VM dos et al. - Widespread hematogenous metastases and Trousseau's syndrome in gastric adenocarcinoma. Rev. Hosp. Clín. Fac. Med S. Paulo 56(3):91-96, 2001.

A case of widespread hematogenous metastases and Trousseau's syndrome is reported in a 40 year-old white housewife with gastric cancer, presenting subdural hematoma, ecchymoses, epistaxis, stomach and uterine bleeding. After undergoing hematoma drainage, she was unsuccessfully treated with platelets, red blood cells, plasma cryoprecipitate transfusions, and antibiotics. Necropsy disclosed gastric ring-signet adenocarcinoma invading the serous layer, with massive disseminated intravascular coagulation and systemic neoplastic embolism. Multiple old and recent hyaline (rich in fibrin and platelets) microthrombi, and tumor emboli were observed in the bone marrow, meninges, liver, lungs, kidneys, lymph nodes, adrenals, thyroid, heart, pancreas, and ovaries (Krukenberg tumor).

DESCRIPTORS: Trousseau's syndrome. Disseminated intravascular coagulation. Subdural hematoma. Gastric cancer. Krukenberg tumor.

Haemostatic abnormalities, manifested as hemorrhage or thrombosis, often occur in patients with advanced cancer of the stomach, pancreas, liver, ovary, breast, lung, and prostate. Clinical features of disseminated intravascular coagulation (DIC) may be acute or chronic, usually following venous thromboembolism ${ }^{1-4}$.

The diagnosis of gastric cancer often occurs first, but there are an increasing number of associations with DIC and microangiopathic hemolytic anemia (MHA), a condition that implies the worst prognosis ${ }^{1-11}$. Although bone metastases are uncommon in gastric cancer, this solid tumor has been the cause of DIC following diffuse bone marrow metastases ${ }^{1-3,6,8-12}$. Extra gastric signs and symptoms may precede the diagnosis of gastric cancer, including acanthosis nigricans, neuromyopathy, central nervous system disturbances, and Trousseau's syndrome. In 1865, the French physician Armand Trousseau (1801-1867) described migratory venous thromboses occurring in the course of his own pancreatic cancer.

The term Krukenberg tumor (Friedrich Krukenberg, German pathologist) refers to bilateral metastases of mucin producing gastrointestinal

From the Department of Internal Medicine and the Pathology Post-Graduation Course, Triângulo Mineiro Medical School, Minas Gerais. cancer (stomach, biliary tree, pancreas) into the ovaries.

DIC is often observed in advanced cancer patients due to acute or insidious development of disseminated fibrin microthrombi, and may simulate primary hematological disease $e^{2,4,6,13}$. Occasionally, acute DIC may be one of the earliest manifestations of gastric cancer $^{2}$, and the course of the disease is rapidly fatal in patients not receiving chemotherapy ${ }^{2,3}$.

In this case, the DIC was the initial manifestation of a clinically unsuspected gastric cancer. We report the complete postmortem examination and highlight the importance of clinical suspicion in the diagnosis of this ominous condition. 


\section{CASE REPORT}

A 40-year-old white housewife came to the hospital on May 10, 1999 complaining of a continuous 3-week headache, which had become more severe in the last 48 hours. She had been using meloxicam, without any improvement. She also presented dizziness, vomiting, ecchymosis, epistaxis, melena, metrorrhagia, mental confusion, and lethargy. Physical examination showed a bad general status, pale mucosa, and no peripheral edema. There was anisocoria (right $>$ left) and lack of photo motor reflex and nuchal stiffness. Anthropometric data revealed body mass index $31.6 \mathrm{~kg} / \mathrm{m}^{2}$. Body temperature was $36.5{ }^{\circ} \mathrm{C}$. The heart was normal, without murmurs, with 78 bpm, and blood pressure was 140/70 $\mathrm{mmHg}$. The lungs, liver, and lymph nodes were normal on initial examination.

The patient's blood group was B, Rh-positive. The erythrocyte count was $3.5610^{6} / \mathrm{mm}^{3}$, with polychromasia and anisocytosis, erythroblasts $6 \%$, hemoglobin $10 \mathrm{~g} / \mathrm{dl}$, hematocrit $32 \%$, MCV $89.8 \mathrm{fL}$, leukocyte count $10,000 / \mathrm{mm}^{3}$ (neutrophils: bands $11 \%$, segmented $65 \%$, eosinophils $2 \%$, lymphocytes $13 \%$, monocytes $9 \%$ ), platelets $71,000 /$ $\mathrm{mm}^{3}$, glucose $110 \mathrm{mg} / \mathrm{dL}$, urea $42 \mathrm{mg} /$ $\mathrm{dL}$, creatinine $0.8 \mathrm{mg} / \mathrm{dL}$, sodium 138 $\mathrm{mEq} / \mathrm{L}$, potassium $3.8 \mathrm{mEq} / \mathrm{L}$, chloride $113 \mathrm{mEq} / \mathrm{L}$, calcium $9 \mathrm{mg} / \mathrm{dL}$, phosphorous $3.7 \mathrm{mg} / \mathrm{dL}$, magnesium 2.1 $\mathrm{mg} / \mathrm{dL}$, total bilirubin $2.3 \mathrm{mg} / \mathrm{dL}$, indirect bilirubin $1.2 \mathrm{mg} / \mathrm{dL}$, AST $42 \mathrm{U} / \mathrm{L}$, ALT $50 \mathrm{U} / \mathrm{L}, \mathrm{gGT} 161 \mathrm{U} / \mathrm{L}$, alkaline phosphatase $347 \mathrm{U} / \mathrm{L}$, fibrinogen 1.15 $\mathrm{g} / \mathrm{L}$, and prothrombin activity $36 \%$. Antinuclear antibody and LE cells tests and rheumatoid factors were negative, and C-reactive protein was positive. The bone marrow aspirate showed intense erythroid hyperplasia, dyserythropoiesis, several mitosis, cytoplasmic bridges, megaloblasts and micro erythroblasts, relative myeloid hypoplasia and cells in all phases of maturation, moderate megakaryocytic hyperplasia, and normal histiocytic and lymphoplasmocytic elements. A computed tomography of the brain revealed a chronic subdural hematoma in the right parietal region, and surgical drainage was performed. In spite of treatment with plasma cryoprecipitate, platelets, and red blood cell transfusions, plus ceftriaxone and gentamicin, the clinical status worsened. There was fever $\left(37.8^{\circ} \mathrm{C}\right)$, more intense jaundice (bilirubins: direct 3.25 and indirect $1.53 \mathrm{mg} / \mathrm{dL}$ ), and higher liver enzymes (AST 144, ALT 51 and gGT 218 U/L). On the fourth day after admission, after severe epistaxis and hematemesis, she died due to irreversible circulatory shock.

Pathologic study. An ulcerated adenocarcinoma (diameter $3 \mathrm{~cm}$ ) infiltrating the serosa layer, with cells showing intense atypia and several mitoses, and some containing mucicarminepositive material (Fig. 1), were detected in pyloric antrum. There was widespread embolism in vessels from the stomach wall and esophagus submucosa, in addition to submucosa and serosa vessels from the small intestine.
Hemorrhage through multiple punctiform lesions in the gastric and intestinal mucosa and diffuse hypotrophic gastritis were also noted.

The dura mater examination showed signs of drained subdural hematoma, hemosiderin impregnation, metastatic emboli, and hemorrhage (Figs. 2A and 2B). The encephalon weighed $1,300 \mathrm{~g}$, showing recent cortical hemorrhage in the right parietal lobe and diffuse edema plus hyperemia. In bone marrow, there was neoplastic infiltration (Fig. 3) and areas of fibrosis. The heart weighed 310 $\mathrm{g}(0.37 \%$ of body weight $)$ with neoplastic emboli in the myocardium and multiple petechial hemorrhages in epicardium. Marantic endocarditis was not found. The lungs weighed $500 \mathrm{~g}$ (right) and $530 \mathrm{~g}$ (left), with multiple fibrin emboli and small metastatic focuses around the vessel walls. There was evidence of some hyaline thrombi canalization and several hemorrhagic foci, with edema and parenchyma collapse, in addition to subpleural petechia and bilateral bloody pleural effusion. Trachea and bronchi were full of bloody material. The thyroid showed multiple metastases. The liver weighed 3,670 g, with several whitish nodes, massive em-

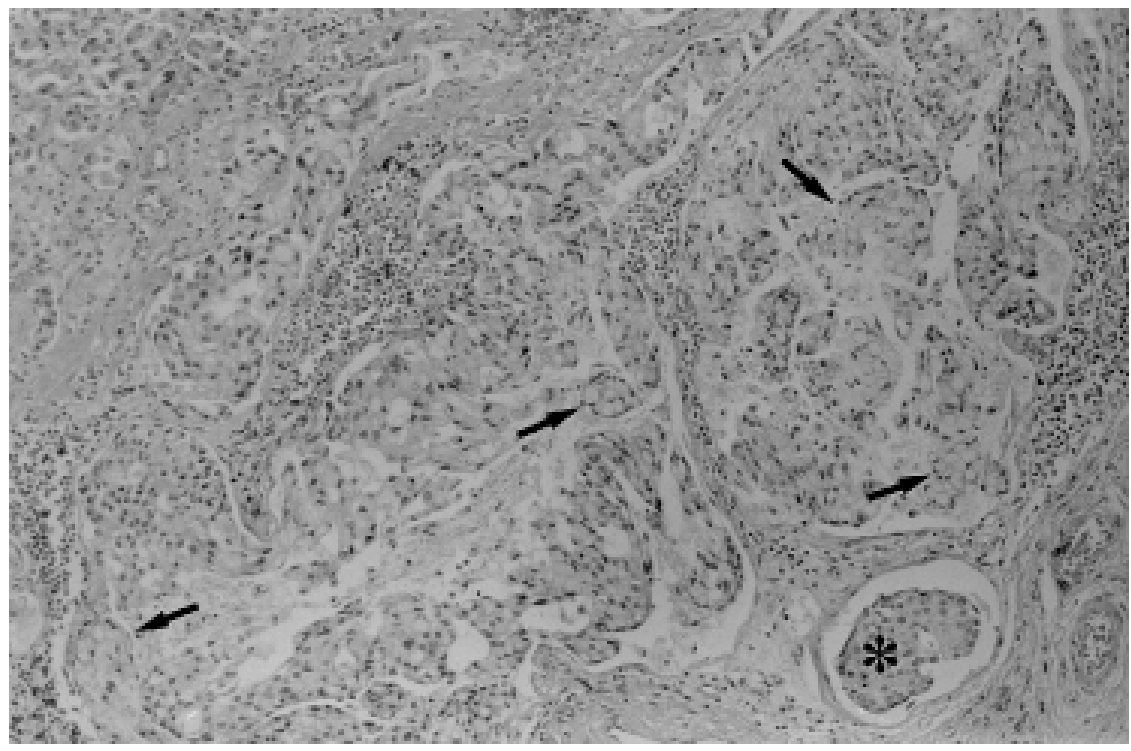

Figure 1 - Mucin containing signet-ring cells of invasive gastric adenocarcinoma (arrows), and neoplastic embolus (*) in gastric vessels (hematoxylin-eosin X 125). 


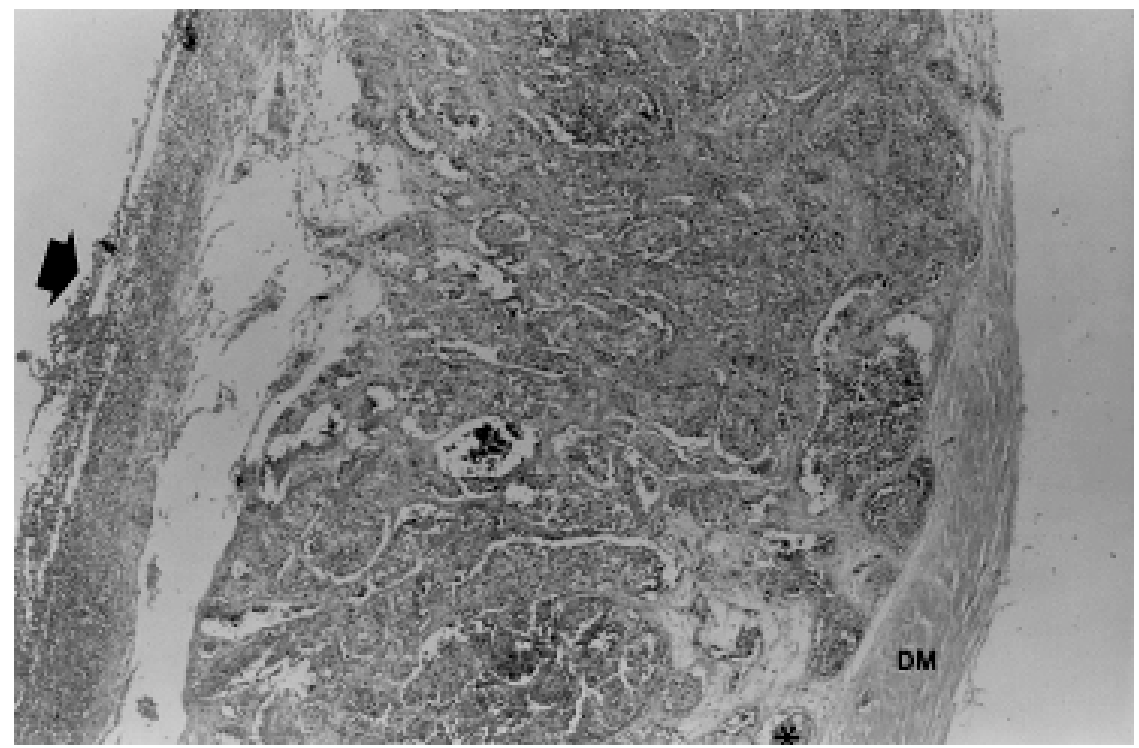

Figure 2A - Subdural hemorrhage (arrow), in addition to neoplastic embolus $(*)$ and dura mater (DM) infiltration (hematoxylin-eosin X 50).

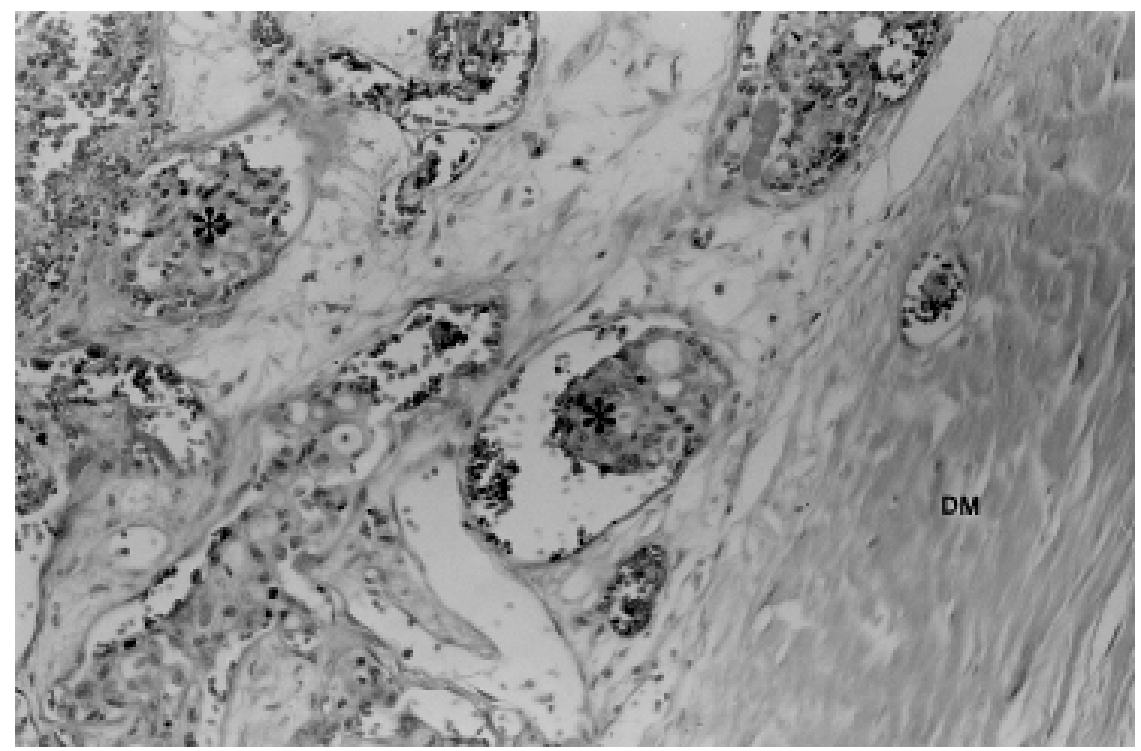

Figure 2B - Detail of neoplastic emboli (*) into dura mater (DM) vessels (hematoxylin-eosin X 200).

boli in portal vein branches (Fig. 4), hilar lymph node metastases, discrete foci of macro vesicular steatosis, diffuse congestion, and jaundice. Microscopic metastases and cytosteatonecrosis were observed in the pancreas. The kidneys weighed $180 \mathrm{~g}$ each, with bilateral neoplastic emboli, fibrin thrombi in small vessels and glomerular capillaries, reduction of cortical thickness, and medullar congestion. In the retroperitoneum, there were lymph node and nerve ganglion metastases, widespread vessel emboli (including vasa-vasorum), and hemorrhage around the inferior vena cava and aorta. The adrenals showed cortical and medullar metastases, and intense cortical hypotrophy. The uterus showed myometrial neoplastic emboli and endometrial hemorrhage. In the ovaries, there were bilateral metastases - the Krukenberg tumor (Fig. 5).

\section{DISCUSSION}

This 40-year-old female with mucin-producing gastric adenocarcinoma (signet-ring cells) presented DIC, petechiae, ecchymoses, epistaxis, stomach and uterine bleeding, bloody pleural effusion, anisocoria, and subdural hematoma, in addition to hemorrhagic foci and neoplastic embolism, mainly in the subarachnoidal vessels.

In necropsies of cancer patients, the frequency of thromboses increases with age, especially in cases of tumors producing thromboplastic substances, such as mucin (esophagus, stomach, pancreas, and colon) $)^{2,4,5,14}$. However, similar to this case, DIC and MHA in younger patients and precocious bone marrow metastases have been reported in gastric cancer ${ }^{2,3,6,8-11,15}$.

Neoplastic cells may generate thromboembolic phenomena through direct lesion of the endothelium, activation of the coagulation cascade, production of procoagulant substances, or reduction in the synthesis or activity of anticoagulant factors ${ }^{2,5,8}$. The tumorderived procoagulant factor that converts factor $\mathrm{X}$ to $\mathrm{Xa}$, favoring thrombin formation, fibrinogen consumption, and fibrin microthrombi production, has been reported to respond well to chemotherapy with 5-fluorouracil ${ }^{8,11}$. In this patient, the subdural hematoma could have had its origin in venous thrombi of the dense external layer of the dura mater, following the rupture of capillaries in the internal areolar layer, and the hemorrhage may have been favored by coagulation disturbances due to DIC $\mathrm{D}^{4,6,9-11,15}$.

In 4,906 consecutive necropsies it was found only 88 cases $(1.8 \%)$ of DIC; forty were patients with cancer ( $82.5 \%$ had metastases in 2 or more sites), and 11 were cases of gastric cancer $(27.5 \%)^{4}$. In 109 patients there was a clinical suspicion of DIC, but the diagnosis was confirmed in 25 cases (23.0\%); while among the remaining 


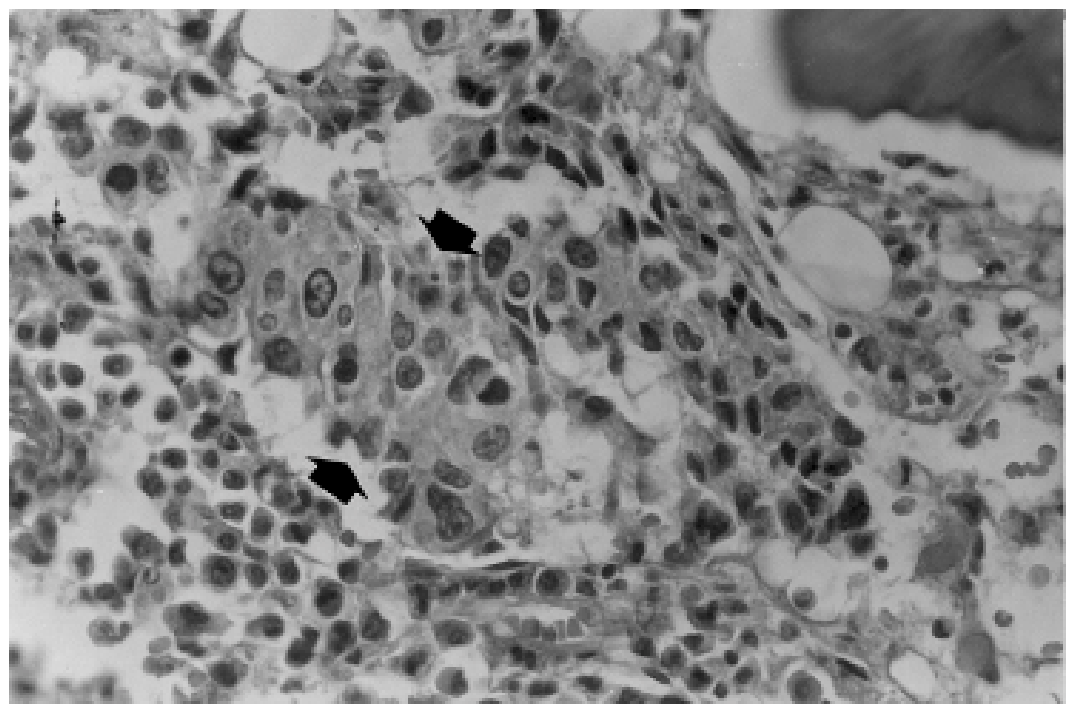

Figure 3 - Neoplastic infiltrate (arrows) in bone marrow (hematoxylin-eosin X 500).

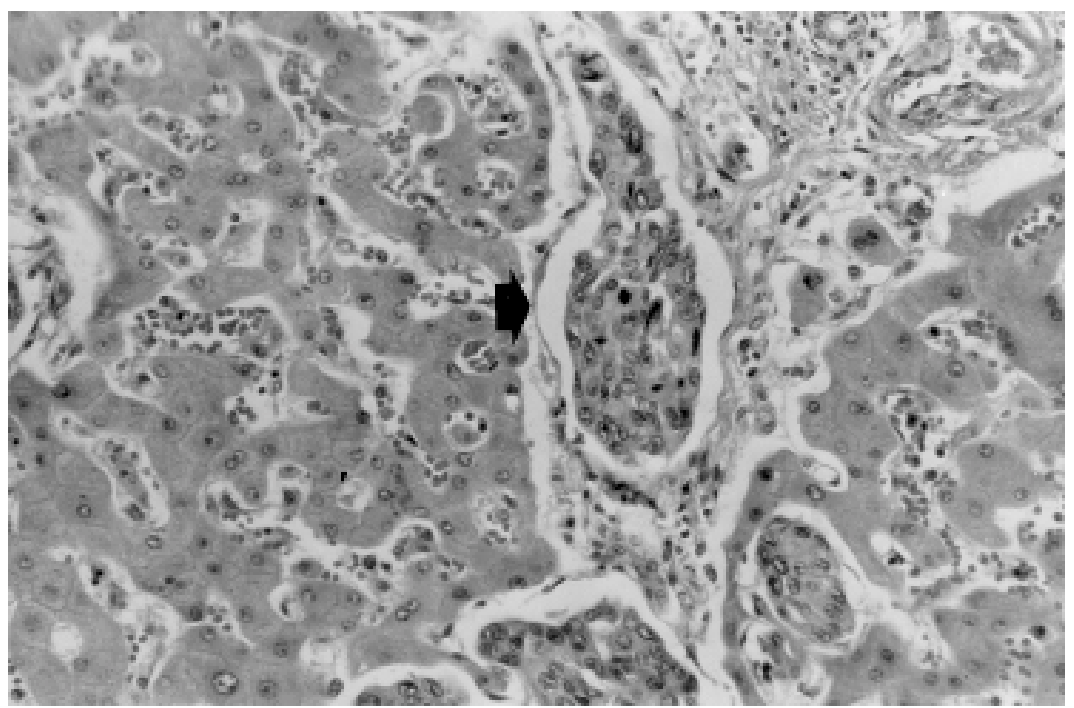

Figure 4 - Neoplastic embolism (arrow) in portal vein branches (hematoxylin-eosin X 250).

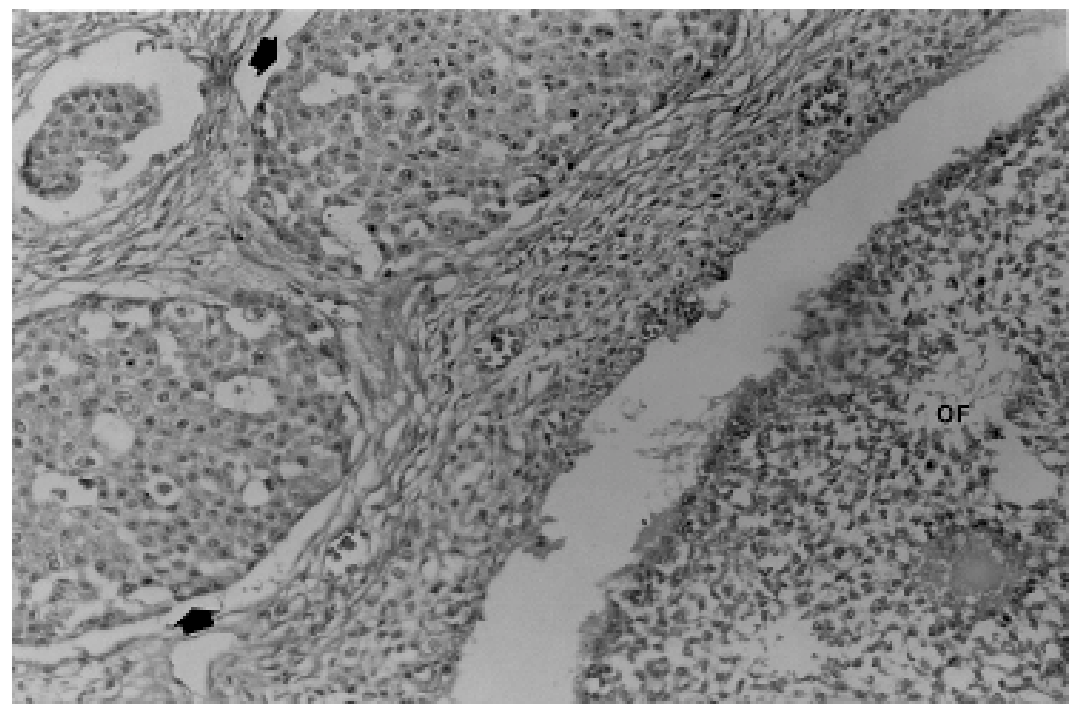

Figure 5 - Metastases of adenocarcinoma (arrows), and normal follicle (OF) in the ovary (hematoxylin-eosin X 200).
4,797 patients without clinical suspicion of DIC, in 63 cases $(1.3 \%)$ microthrombi were present in 3 or more sites. Fibrin microthrombi were more frequently found in the kidney, followed by the lungs, spleen, adrenals, heart, brain, and liver ${ }^{4}$.

Either massive or disseminated microthrombi may cause infarctions in vital organs, as well as respiratory, renal, hepatic, and/or heart failure ${ }^{7,13}$ predisposing to irreversible circulatory shock $^{14}$.

Histopathologic criteria to confirm the diagnosis of DIC consist of demonstration of fibrin microthrombi in arterioles, capillaries, and venules, in at least 3 different organs ${ }^{4}$.

In the present case, skin manifestations suggesting migratory or recurrent thrombophlebitis were absent; nevertheless, the low platelet count and prolonged prothrombin time, in addition to the unequivocal demonstration of disseminated fibrin microthrombi in more than 3 different organs, allowed us to establish the diagnosis of DIC ${ }^{4,13}$.

As occurred in this case, the association of disseminated cancer with multiple venous and arterial thomboembolic phenomena, including DIC, has been considered as a variant of the classic Trousseau's syndrome ${ }^{5}$.

Another concern could be the normal plasma fibrinogen; however, in some patients with DIC, the fibrinogen levels have been described to lower more slowly, in part due to higher hepatic production under influence of severe stress ${ }^{13}$.

The patient did not undergo chemotherapy; in spite of treatment with platelets, red blood cells, and plasma cryoprecipitate transfusions, she presented signs of respiratory, renal, and hepatic failure and circulatory shock, and she died in 4 days. In this case, the nonsteroidal anti-inflammatory drug (meloxican) may have contributed to the severity of bleeding associated with multiple punctiform lesions observed 
in the gastric and intestinal mucosa.

In adults, the sudden appearance of DIC in the absence of infection or bone marrow primary disease should stimulate a strong suspicion of gastric can- $\operatorname{cer}^{2,4}$, and if diagnosis is confirmed, an initial schedule of nonmyelosuppressive chemotherapy with 5-fluorouracil must be started as soon as possible. By increasing the survival time of patients with gastric cancer and DIC, chemotherapy with 5-fluorouracil allows further employment of complementary antineoplastic therapies ${ }^{11}$.
SANTOS VM dos e col. - Metástases hematogênicas disseminadas e síndrome de Trousseau em adenocarcinoma gástrico. Rev. Hosp. Clín. Fac. Med. S. Paulo 56(3):9196, 2000.

Relata-se caso de metástases hematogênicas disseminadas e síndrome de Trousseau em mulher branca de 40 anos, portadora de câncer gástrico, apresentando hematoma subdural, equimoses, epistaxes, hemorragia gástrica e metrorragia. Inicialmente submetida à drenagem do hematoma, foi tratada sem sucesso com transfusões de plaquetas, hemácias e plasma crioprecipitado, além de antibióticos. O estudo de necropsia revelou adenocarcinoma gástrico com células em anel de sinete invadindo a serosa, com maciça coagulação intravascular disseminada e embolismo neoplásico sistêmico. Microtrombos hialinos (constituídos de fibrina e plaquetas) antigos e recentes, além de êmbolos tumorais, foram observados na medula óssea, meninges, fígado, pulmões, rins, linfonodos, adrenais, tireóide, coração, pâncreas e ovários (tumor de Krukenberg).

DESCRITORES: Síndrome de Trousseau. Coagulação intravascular disseminada. Hematoma subdural. Câncer gástrico. Tumor de Krukenberg.

\section{REFERENCES}

1. NIEL F, GAUSSEM P, ANDREUX MH et al. - Cancer généralisé chez une femme de 82 ans: envahissement médullaire et coagulation intravasculaire disséminée. Ann Biol Clin 1998; 56: 580-3.

2. PASQUINI E, GIANNI L, AITINI E et al. - Acute disseminated intravascular coagulation syndrome in cancer patients. Oncology 1995; 52: 505-8

3. SUSANO R, CAMINAL L, FERRO J et al. - Anemia hemolítica microangiopática asociada a neoplasias: análisis de cinco casos y revisión de la literatura. Rev Clin Esp 1994; 194: 603-6.

4. TANAKA $K \&$ IMAMURA $T$ - Incidence and clinicopathological significance of DIC in autopsy cases. In: ABE T \& YAMANAKA $M$ - Disseminated Intravascular Coagulation. Bibliotheca Haematologica Series. Bern, Hässig A, 1981. p. 79-83.
5. CAFAGNA D \& PONTE E - L'embolia polmonare da causa paraneoplastica. Minerva Med 1997; 88:523-30.

6. COLOMBO E, GIORGI S, SONZINI E et al. - Disseminated intravascular coagulation and bone marrow metastases as presenting manifestations of gastric carcinoma. Haematologica 1985;70: 187.

7. ISHIKAWA M, SUSUKI S, AKUTU Y et al. - An autopsy case of AIDS with hemophilia A who died of DIC and gastrointestinal bleeding associated with gastric carcinoma (signet ring cell carcinoma). Jpn J Clin Hematol 1994; 35: 886-91.

8. KORTE W \& FLURY R - Acquired factor X deficiency and disseminated intravascular coagulation in a case of metastasizing carcinoma of the stomach and its course under chemotherapy. Ann Hematol 1992; 64: 152-4. 
9. MORIMATSU M, SHIROUZU K, IRIE K et al. - Gross and microscopic characteristics of stomach cancer with microangiopathic hemolytic anemia and/or disseminated intravascular coagulopathy. Acta Pathol Jpn 1985; 35: 809-22.

10. TAKEUCHI R, KUTO M, KATAYAMA N et al. - A case of carcinomatosis associated with microangiopathic hemolytic anemia and disseminated intravascular coagulation occurring after 12 years of operation for gastric cancer. Jpn J Clin Hematol 1983; 24 $1423-9$.

11. YEH K-H \& CHENG A-L - Gastric cancer associated with acute disseminated intravascular coagulation: successful initial treatment with weekly 24-hour infusion of high-dose 5-fluorouracil and leucovorin. Br J Hematol 1998; 100: 769-72.
12. NODA N, SANO T, SHIRAO K et al. - A case of bone marrow recurrence from gastric carcinoma after a nine-year disease-free interval. Jpn J Clin Oncol 1996; 26: 472-5.

13. HARDAWAY RM \& WILLIAMS CH- Disseminated intravascular coagulation: an update. Compr Ther 1996; 22: 737-43.

14. BRESCIANI C, BORGES PCM, GAMA-RODRIGUES JJ et al. Fatal pulmonary thromboembolism in gastrectomy intraoperative procedures by gastric adenocarcinoma: Case report. Rev Hosp Clín Fac Med S Paulo 1999; 54: 115-20.

15. FURUI T, ICHIHARA K, IKEDA A et al. - Subdural hematoma associated with disseminated intravascular coagulation in patients with advanced cancer. J Neurosurg 1983; 58: 398-401.

Received for publication on November 13, 2000 